\title{
Arqueología del grafiti. Estratos del lienzo urbano
}

\author{
Víctor Almirón Casado | Arqueólogo \\ URL de la contribución <www.iaph.es/revistaph/index.php/revistaph/article/view/4939>
}

El arte urbano es una expresión en gran medida efímera de un movimiento cultural que mañana será un "clásico". Por tanto, urge actuar hoy para que, al menos, su registro gráfico perdure en el tiempo y además se clarifiquen la consideración patrimonial y conservación de determinadas obras por sus valores culturales, aceptación social o la conjunción de estas y otras circunstancias.

Para ello, se apuntan en este artículo diversas medidas futuras de preservación. Puesto que mi formación académica proviene de la arqueología, me resulta atractiva la idea de abordarlas desde una "perspectiva estratigráfica", algo que pudiera parecer ajeno en primera instancia pero es perfectamente compatible y útil, como se mostrará más adelante con un ejemplo literal de dicho método analítico.

En el paisaje urbano actual se representan gran cantidad de expresiones que se mueven dentro del mundo del grafiti -desde los stickers al tag pasando por pinta-

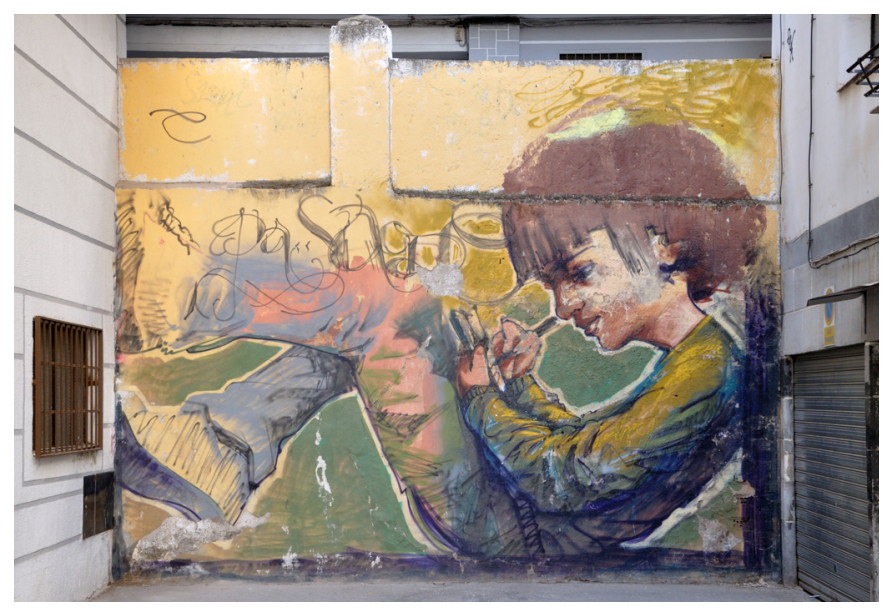

Mural de El niño de las pinturas en el barrio del Realejo, Granada | foto Gwen Fran das reivindicativas e incluso de notable talento literario, hasta llegar a las composiciones murales más complejas-. Todo esto conforma un "estrato urbano", síntoma y reflejo de las dinámicas sociales actuales. Podría decirse que una de las evidencias materiales que identificaría a la sociedad de finales del siglo XX, y del siglo XXI es la presencia del arte urbano en las calles. Esta aproximación o juego asociativo entre la terminología arqueológica y el mundo del arte urbano nos sirve también como eje cronocultural.

La propuesta podemos plantearla en dos vertientes. Una de ellas sería la "estratigrafía digital del lienzo urbano". Se trataría de que las instituciones culturales impulsaran la creación de un registro documental de imágenes, manteniéndolo actualizado e incorporando material disponible a lo largo de los años para poder ofrecer una visión de muy fácil consulta sobre el proceso de superposición.

Así, obtendríamos imágenes bien documentadas de un mismo soporte que al cabo de los años mostrarían las capas que cuentan su pasado; este registro debería contar con la participación de los artistas de modo que pudieran aportar imágenes y cualquier información de interés para la ficha de cada elemento, donde se incluirían, además de la identificación de la autoría, una valoración estilística, los materiales empleados o los tipos de trazos ejecutados, además de cualquier otro detalle relevante. Añadidos a los datos anteriormente citados se incorporarán claves sociales, culturales, políticas o económicas de cada fotograma, fácilmente ampliables mediante enlaces, códigos QR y otros recursos ya de uso cotidiano. Por otra parte, el formato digital permitiría su evolución creativa para ser transformado y utilizado con un bajo coste en exposiciones, conciertos, publicaciones o cualquier otra manifestación y soporte. 

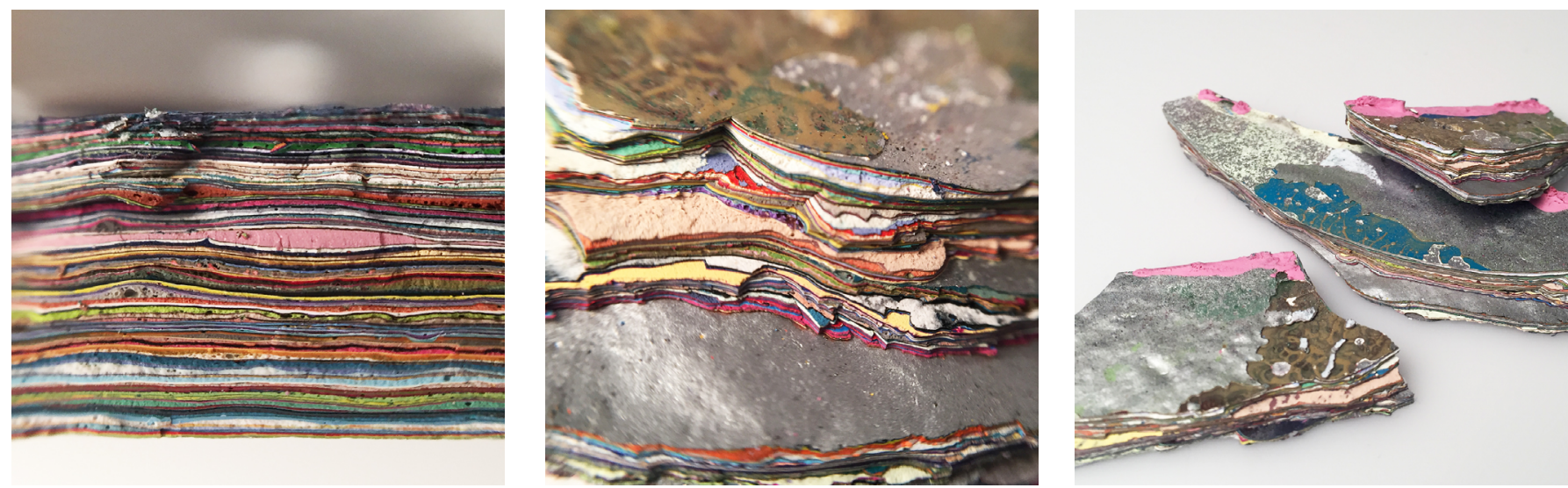

Estratigración de un muro. Paul De Graaf extrajo varios fragmentos de la pared de un edificio que había sido grafiteado desde la década de 1980 | fuente Yuste (2017)

La segunda vertiente iría encaminada hacia la realización de una labor in situ de identificación estratigráfica, una evaluación del soporte mural para conocer directamente la historia que cuentan sus capas desde el punto de vista técnico, inclusive a partir de fragmentos. Si fuese necesario se podría establecer su estado de conservación y plantear su posible intervención. A este enfoque analítico se suma el interés sociológico, ya que el uso reiterado de un espacio refleja diversas realidades.

Al hilo de lo anterior encontramos un caso en Nijmegen (Países Bajos) donde Paul De Graaf extrajo varios fragmentos de la pared de un edificio que lleva siendo grafiteado desde los años 80. El ejercicio consistió en constatar dichos restos murales, creados por superposición de capas de pigmento, e identificarlos como "marcadores arqueológicos". El resultado fue una lectura estratigráfica -en este caso simbólica-, donde se fecharon algunos hitos destacados que acontecieron a lo largo de la historia de esos muros (Yuste 2017).

La viabilidad del método propuesto permite utilizarlo análogamente en cualquier contexto urbano, haciendo posible completar una lectura más precisa de la vida y, en muchas ocasiones, del ocaso de las piezas de arte urbano. A pesar de su condición transgresora y su carácter efímero -con notables excepciones-, el movimiento no tiene necesariamente que desaparecer sin dejar hue-
Ila. En este sentido Young decía lo siguiente: "Yesterday's vandalism may yet be tomorrow's heritage"-el vandalismo de ayer puede ser el legado del mañana- (Young $2014,150)$. Esta reflexión recoge bastante bien los ideales que engloba y adelanta que, a pesar de todas las reticencias, cautelas y lógico debate, estamos viendo que la sociedad, la academia y las instituciones están apuntando su interés hacia el arte urbano.

Se podría decir que todos somos espectadores pasivos y jueces formales de todo aquello que ocurre en nuestras calles en relación con lo estético. Hemos sido capaces de resignificar ciertas expresiones plásticas urbanas al otorgarle un marco identitario común. Es aquí donde subyace el demostrado poder de transformación social, con capacidad suficiente como para recuperar entornos social y físicamente degradados. Asistimos por tanto al proceso evolutivo de un ente vivo; el arte urbano se postula como el nuevo patrimonio de la calle. Por lo tanto, nos encontramos ante la dicotomía de si realmente se nos presenta como una propuesta patrimonial de futuro o ya lo es de presente.

La lectura formal del mundo artístico suele venir acompañada de un marco simbólico que arropa la obra -algo que funciona de la misma manera en el ámbito arqueológico-. Es el caso de la reivindicación del artista británico Banksy en su obra Arte rupestre, en la que muestra 
a un operario "limpiando" con agua a presión un panel con arte parietal prehistórico. Con el arte urbano como instrumento se nos ofrece una interpretación evidente: la pérdida que supone la eliminación del registro patrimonial, la necesidad de preservar y alentar el impulso humano por expresar aquello que lo identifica como individuo y lo asocia culturalmente como grupo, que eleva el afán de plasmar "su realidad", una realidad que, como se viene defendiendo, se superpone y estratifica, ya sea en la cueva de Lascaux (Francia) o en el Bronx (Nueva York).

La mencionada resignificación del espacio urbano muestra la concepción que se está dando actualmente dentro del movimiento, hasta tal punto que llegamos a asociar ciertas zonas con un gran lienzo de color, como sucede en el barrio del Realejo de Granada. Esto ha sido posible gracias a la revalorización identitaria de aquellos que conviven con el arte de calle, y se postula como elemento trascendental para abordar parte del debate que nos atañe.

Las cuestiones anteriormente expuestas nos están marcando las pautas evolutivas del movimiento. Es cierto que no podemos obviar su carácter efímero, pero ante la inminente desaparición de ciertas expresiones artísticas que ocurren a diario en nuestras calles, se nos abre una necesaria vía de salvaguarda. Afortunadamente podemos abordar el análisis de dichas expresiones desde lo multidisciplinar, sin olvidar que tanto la sociedad como aquellos artistas implicados precisan de voz y voto en la estructuración de un horizonte patrimonial referido al arte urbano.

Asistimos por suerte a un cambio en la pauta de comprensión y estima del arte urbano ya que, el simple hecho de que se abra la posibilidad de debatir sobre qué herramientas son necesarias para estudiarlo y documentarlo como elemento patrimonial a reconocer, evidencia el interés social que juega en favor de su registro. Dado ese interés, es de vital importancia no elevar un discurso estrictamente academicista, es decir, no debemos obviar la realidad cambiante de aquello que ocu- rre en el entorno urbano. Por lo tanto, el discurso debe construirse bajo una narrativa que una ambos mundos, de este modo evitaremos la "domesticación" del arte urbano.

\section{BIBLIOGRAFÍA}

- Young, A. (2014) Street art, public city: crime and the urban imagination. Abingdon: Routledge

- Yuste, J. (2017) 30 años de graffiti crean una colorida estratificación en un muro y revelan décadas de arte urbano. Cultura Inquieta, 15 de junio de 2017. Disponible en: https:// culturainquieta.com/es/arte/street-art/item/12167-30 de junio de-anos-de-graffiti-crean-una-colorida-estratificacion-en-unmuro-y-revelan-decadas-de-arte-urbano.html [Consulta: 26/04/ 2021] 